\title{
Editorial
}

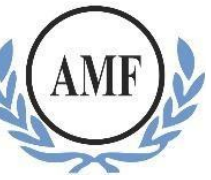

\section{Prezado leitor,}

Com satisfação, no ano em que a Saber Humano, Revista Científica da Antonio Meneghetti Faculdade comemora seus 10 anos, temos a satisfação de apresentar à comunidade academia e pública em geral sua edição de número 10 e volume 17.

Esta edição é aberta com um rico trabalho de tradução que apresenta, de modo inédito no Brasil e em língua portuguesa o artigo intitulado: Identidade Frágil: respeito ao outro e identidade cultural do filósofo francês Paul Ricoeur. A seção Ontopsicologia é aberta com um ensaio do Prof. Dr. Alécio Vidor. Este texto é a transcrição de sua fala no histórico momento de formatura da $1^{\text {a }}$ turma do curso de Bacharelado em Ontopsicologia da Antonio Meneghetti Faculdade. O mesmo visa ressaltar o compromisso pessoal de autenticação daqueles se dedicam ao exercício da Ontopsicologia. Ainda nesta seção, dois trabalhos apresentam a aplicação da Ciência Ontopsicológica, Tocar para Ser: a Ontopsicologia como fundamento da identidade da Orquestra Jovem Recanto Maestro, no âmbito da cultura humanista e Estudo Exploratório sobre a causalidade psíquica em paciente com queixa de zumbido crônico, no âmbito da psicossomática.

A seção Administração recebe o texto Riscos corporativos: estudo de caso em uma empresa prestadora de serviços no âmbito da gestão estratégica e de riscos. A seção Direito publica o texto As redes de inovação sob a premissa do comunitarismo: ambientes para geração da inovação tecnológica na universidade relacionando a perspectiva do comunitarismo responsivo e a inovação tecnológica. Por fim, a seção Interdisciplinar apresenta Saúde mental no ambiente organizacional: os desafios de uma comunicação eficaz e não violenta com os trabalhadores, refletindo os desafios atuais da eficácia comunicativa na gestão; A influência do lean healthcare para gestão hospitalar que discute o profissional na gestão hospitalar e Barreiras de Acessibilidade Enfrentadas por Pessoas Surdas no Setor de Serviços: Uma Revisão Integrativa da Literatura apontando para a problemática da inclusão e acessibilidade. 
Desejamos ao leitor uma profícua leitura, bem como, agradecemos o contínuo trabalho de excelência realizados pelos avaliadores e toda a equipe editorial da Saber Humano: Revista Científica da Antonio Meneghetti Faculdade e nosso especial agradecimento aos autores que aqui tiverem seus textos publicados. Neste mesmo espírito de comunidade científica fazemos votos de boas festas e um excelente 2021 !

\section{Cordiais Saudações}

Prof. Ms. Bruno Fleck da Silva, editor-chefe. 